\title{
Chemical Applications, Scarification and Stratification Effects on Seed Germination of Rare Endemic Verbascum calycosum Hausskn. ex Murb. (Scrophulariaceae)
}

\author{
Muhip HİLOOĞLU ${ }^{1}$, Emel SÖZEN ${ }^{1 *}$, Ersin YÜCEL ${ }^{1}$, Ali KANDEMİR ${ }^{2}$ \\ ${ }^{1}$ Anadolu University, Faculty of Science, Department of Biology, Eskişehir, Turkey; mhilooglu@anadolu.edu.tr; \\ esozen@anadolu.edu.tr(*orrespondingauthor); eyucel@anadolu.edu.tr \\ ${ }^{2}$ Erzincan University, Faculty of Arts and Science, Department of Biology,Erzincan, Turkey; akandemir@erzincan.edu.tr
}

\begin{abstract}
Verbascum calycosum is an endemic plant species having considerable narrow distribution in Erzincan (Turkey) region. This species is known from only a single population and its habitats are highly threatened due to intensive human activities and soil erosion. In this study, the germination behavior of $V$. calycosum under different concentrations of $\mathrm{NaCl}, \mathrm{HCl}, \mathrm{KNO}_{3}$, $\mathrm{GA}_{3}(100$ and $200 \mu \mathrm{M})$, hot-cold stratification and mechanical scarification were investigated. Seeds were exposed to a photoperiod of $8 \mathrm{~h} \mathrm{light} / 16 \mathrm{~h}$ dark with a $23 / 18{ }^{\circ} \mathrm{C}$ thermoperiod. Germination rates increased with $\mathrm{GA}_{3}-100 \mu \mathrm{M}(39 \%)$, $\mathrm{GA}_{3}-200 \mu \mathrm{M}(54.5 \%)$, mechanical scarification (34.5\%) and cold stratification treatments $\left(+4{ }^{\circ} \mathrm{C}, 23.25 \% ;-20^{\circ} \mathrm{C}, 18.25 \%\right)$ on the other hand, $\mathrm{KNO}_{3}, \mathrm{NaCl}, \mathrm{HCl}$ and stratification with hot water treatments have decreased germination rates significantly when compared to the control (12.25\%). Increased germination after $\mathrm{GA}_{3}$ application and mechanical scarification indicated that seeds of $V$. calycosum exhibited both non-deep and intermediate physiological dormancy as well as physical dormancy due to its hard seed coat. The highest speed of germination index was obtained at cold stratification of $+4{ }^{\circ} \mathrm{C}$ and $-20{ }^{\circ} \mathrm{C}(10.3)$. This study represents first report about seed dormancy and germination characteristics of $V$. calycosum. Overall, these results will provide valuable data for ex situ conservation of this rare endemic plant.
\end{abstract}

Keywords: dormancy; endemic; ex situ; germination; Scrophulariaceae; Verbascum

\section{Introduction}

Verbascum L. (Scrophulariaceae) is the largest genus of Turkish flora. This genus is represented by 234 species and 85\% endemism rate in Turkey (Erik and Tarkkahya, 2004). Endemic Verbascum calycosum Hausskn. ex Murb. is a rare plant species that shows narrow distribution around Erzincan province (Turkey). The species was first collected by Sintenis from Kemaliye / Erzincan district in 1890 (Davis, 1978). In Turkey, many endemic plant species considered as a source of genetic diversity are faced with the risk of extinction due to various reasons such as rapid urbanization, industrialization and other anthropological factors. According to the IUCN criteria, $V$. calycosum was evaluated as EX (Extinction) for many years (Ekim et al., 2000). However, it has been rediscovered from its original localities in 1992 and 2004 (Nydegger-Hügli, 2002; Kandemir and Makbul, 2004; Aytaç et al., 2005). $V$. calycosum is represented by a single population located in
Kemaliye, Erzincan. Currently, habitats of this species are highly threatened due to intensive human activities and soil erosion (Kandemir and Makbul, 2004) and recently evaluated as CR (Critically endangered) (Kandemir et al., 2015).

Seed germination is a trait of primary significance for the reproductive success of plants (Bu et al., 2008). Thus, detailed information on the different stages in the reproductive cycle of endemic, rare and threatened species may contribute to improved understanding of the phenomenon of rarity, and at the same time assist conservation management decisions for the species under study (Menges, 1986; Schemske et al., 1994). Seed germination is vital for the long-term preservation of germplasm, and the maintenance of genetic diversity for the conservation of threatened plant species, which has become a global concern over recent decades (Cousins et al., 2014).

It is known that some pre-treatments such as sanding, boiling or cold stratification and chemical applications such as potassium nitrate, acid and gibberellic acid are used in germination studies to break down seed dormancy (Jones $e t$ 
al., 2016; Peng et al., 2017). The aim of this study was to determine the effect of different chemical applications $\left(\mathrm{NaCl}, \mathrm{HCl}, \mathrm{KNO}_{3}, \mathrm{GA}_{3}\right)$ and some pre-treatments techniques (hot/cold and mechanical) on seed germination for the rare endemic $V$. calycosum plant bearing the risk of extinction. The results obtained from this study could provide basic information to develop effective ex situ conservation strategies for this rare and endemic plant.

\section{Materials and Methods}

\section{Plant material and seed collection}

$V$. calycosum is only known from type locality (around Salihli Village in Kemaliye District). Its population is separated by Erzincan-Kemaliye highway and members of the species are sparsely scattered (roughly 8250 individuals) on $15.99 \mathrm{~km}^{2}$ serpentine area. Plant samples of $V$. calycosum were collected from Erzincan ( 37453742 E, $4356278 \mathrm{~N}$, altitude 1370-1488 m), Turkey (Fig. 1) between July and September 2014.

The collected plants were air dried for seven days in room conditions. The mature capsules were carefully harvested. After counting the total number of seeds per fruit, healthy and fully developed seeds were selected under stereomicroscope. The seed weight was determined according to Bonner (1974).

\section{Seed germination experiment}

Seed germination experiments were carried out on filter paper in Petri dishes (9 mm diameter, sterilized) at constant a photoperiod of $8 \mathrm{~h}$ light $/ 16 \mathrm{~h}$ dark with a $23 / 18{ }^{\circ} \mathrm{C}$ thermoperiod. The Petri dishes containing seeds were subjected to different treatments namely:

- Chemical applications; containing sodium chloride $(\mathrm{NaCl})$, hydrochloric acid $(\mathrm{HCl})$, potassium nitrate $\left(\mathrm{KNO}_{3}\right)$, gibberellic acid $\left(\mathrm{GA}_{3}\right)$ solution at $100 \mu \mathrm{M}$ and $200 \mu \mathrm{M}$ concentrations.

- Mechanical scarification; sanding was gently made with sandpaper (grade 150) about $30 \mathrm{sec}$ or $1 \mathrm{~min}$.

- Cold stratification; the Petri dishes were wrapped with aluminium foil and placed at $+4{ }^{\circ} \mathrm{C}$ and $-20{ }^{\circ} \mathrm{C}$ for seven days before transferring to growth chambers.

- Hot stratification; soaking in hot-boiling water for $30 \mathrm{sec}, 1 \mathrm{~min}$ and $2 \mathrm{~min}$.

- Control treatment; distilled water was used to germinate seeds.

Each treatment was replicated 4 times with at least 25 seeds per replication (ISTA, 1985). Seed germination was recorded daily, the radical emergence of $2-5 \mathrm{~mm}$ accepted as a successful germination (Asl et al., 2011).

\section{Data analysis}

The germination percentage (GP) using the equation: "GP = number of germinated seeds / total number of seeds $\mathrm{x}$ 100 " and its angular transformation $(\operatorname{arcsine} \sqrt{G P}$ ) were calculated. Speed of germination (SG) was defined as the number of seeds germinated during a limited period according to the formula described by Yücel (2000):

Germination Speed $(\mathrm{GS})=\sum(\mathrm{G} \times 100) / \sum \mathrm{H}$,

where

$\mathrm{G}=$ Daily germination percent,
$\mathrm{H}($ Daily germination speed $)=\mathrm{G} \times \mathrm{A}$

( $\mathrm{A}=$ Days since sowing).

Time to $50 \%$ germination (T50) was calculated according to the formula of Coolbear et al. (1984) modified by Farooq et al. (2005):

$$
\mathrm{T} 50=\mathrm{ti}(\mathrm{N} / 2-\mathrm{ni})(\mathrm{tj}-\mathrm{ti}) / \mathrm{nj}-\mathrm{ni},
$$

where

$\mathrm{N}$ is the final number of seeds germinated and nj, ni are the cumulative number of seeds germinated by adjacent counts at times tj, ti when ni $<\mathrm{N} / 2<\mathrm{nj}$.

The data were analyzed using the SPSS (Version 15.0, SPSS Inc. Chicago, IL) software and the means were compared with Duncan's Multiple Range Test (DMRT) (P $<0.05)$.

\section{Results}

\section{Seed structure}

The seeds of $V$. calycosum develop in capsules that are usually few in number. Among 20 capsules were randomly examined, one was empty and one contained undeveloped five seeds. In the rest 18 capsules, the number of seeds ranged from 2-37 per capsule. About $47.46 \%$ of the total seeds were found to be healthy. Seed size is about $1 \mathrm{~mm}$ by $1.3 \mathrm{~mm}$ in dimension, ovoid in shape and its outer surface is indented (Fig. 2). Brown-black testa is very hard and seems impervious to water and gases. The weight of 1000 healthy seeds was found as $203 \mathrm{mg}$.

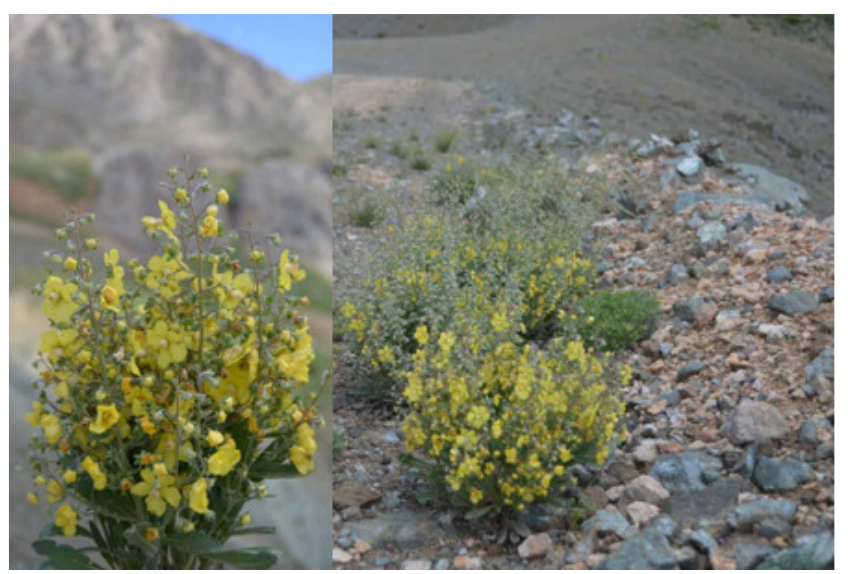

Fig. 1. Verbascum calycosum in its habitat

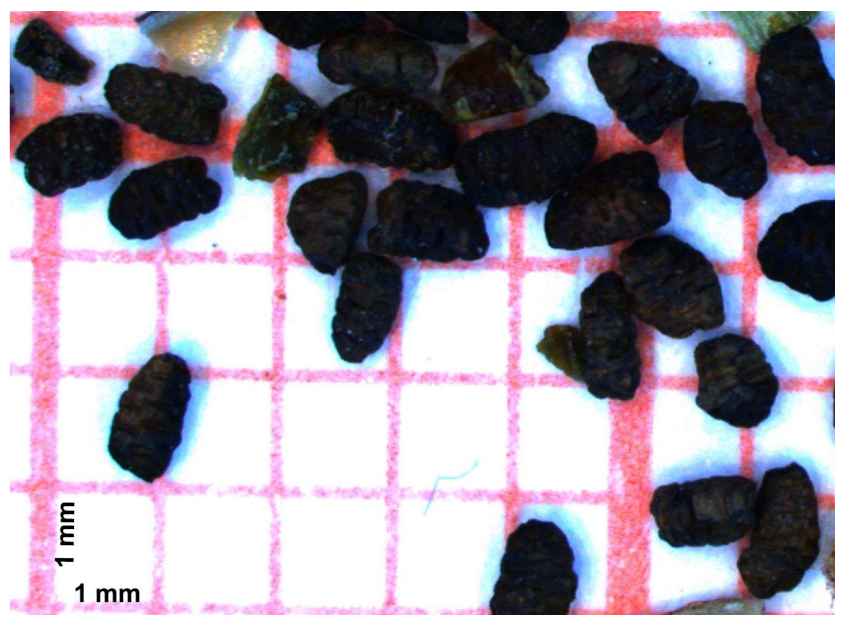

Fig. 2. Seeds of Verbascum calycosum 
Table 1. Mean values of GP, SG, T50 for Verbascum calycosum under different treatments

\begin{tabular}{|c|c|c|c|c|c|}
\hline Treatment & Concentration $(\mu \mathrm{M})$ & GP (\%) & AT & SG & T50 (Day) \\
\hline Control & - & $12.25^{\mathrm{e}}( \pm 1.1)$ & 20.48 & $8.6^{\mathrm{b}}( \pm 1.4)$ & $10^{b}( \pm 0.5)$ \\
\hline $\mathrm{KNO}_{3}$ & 100 & $1^{\mathrm{f}}( \pm 0.2)$ & 5.73 & - & - \\
\hline $\mathrm{KNO}_{3}$ & 200 & $2^{f}( \pm 0.2)$ & 8.13 & - & - \\
\hline GA-3 & 100 & $39^{\mathrm{b}}( \pm 2.4)$ & 38.64 & $7.6^{\mathrm{b}}( \pm 0.7)$ & $12^{\mathrm{a}}( \pm 1.0)$ \\
\hline GA-3 & 200 & $54.5^{a}( \pm 2.9)$ & 47.58 & $7.5^{b}( \pm 0.9)$ & $13^{\mathrm{a}}( \pm 0.8)$ \\
\hline $\mathrm{NaCl}$ & $100-200$ & - & - & - & - \\
\hline $\mathrm{HCl}$ & $100-200$ & - & - & - & - \\
\hline Sandpaper & - & $34.5^{\mathrm{c}}( \pm 1.8)$ & 35.97 & $9.5^{\mathrm{ab}}( \pm 1.0)$ & $11.5^{\mathrm{ab}}( \pm 0.9)$ \\
\hline Hot water $(30 \mathrm{sec})$ & - & $1.25^{f}( \pm 0.3)$ & 6.41 & - & - \\
\hline Hot water $(1 \mathrm{~min})$ & - & - & - & - & - \\
\hline Hot water $(2 \mathrm{~min})$ & - & - & - & - & - \\
\hline Stratification $\left(+4^{\circ} \mathrm{C}\right)$ & - & $23.25^{\mathrm{d}}( \pm 1.5)$ & 28.82 & $10.3^{\mathrm{a}}( \pm 1.1)$ & $8.5^{c}( \pm 0.6)$ \\
\hline Stratification $\left(-20^{\circ} \mathrm{C}\right)$ & - & $18.25^{\mathrm{d}}( \pm 1.4)$ & 25.29 & $10.3^{a}( \pm 0.9)$ & $8.7^{\mathrm{c}}( \pm 0.7)$ \\
\hline
\end{tabular}

GP, SG: Speed of germination, T50: Time to $50 \%$ germination (Standard deviation, in brackets)

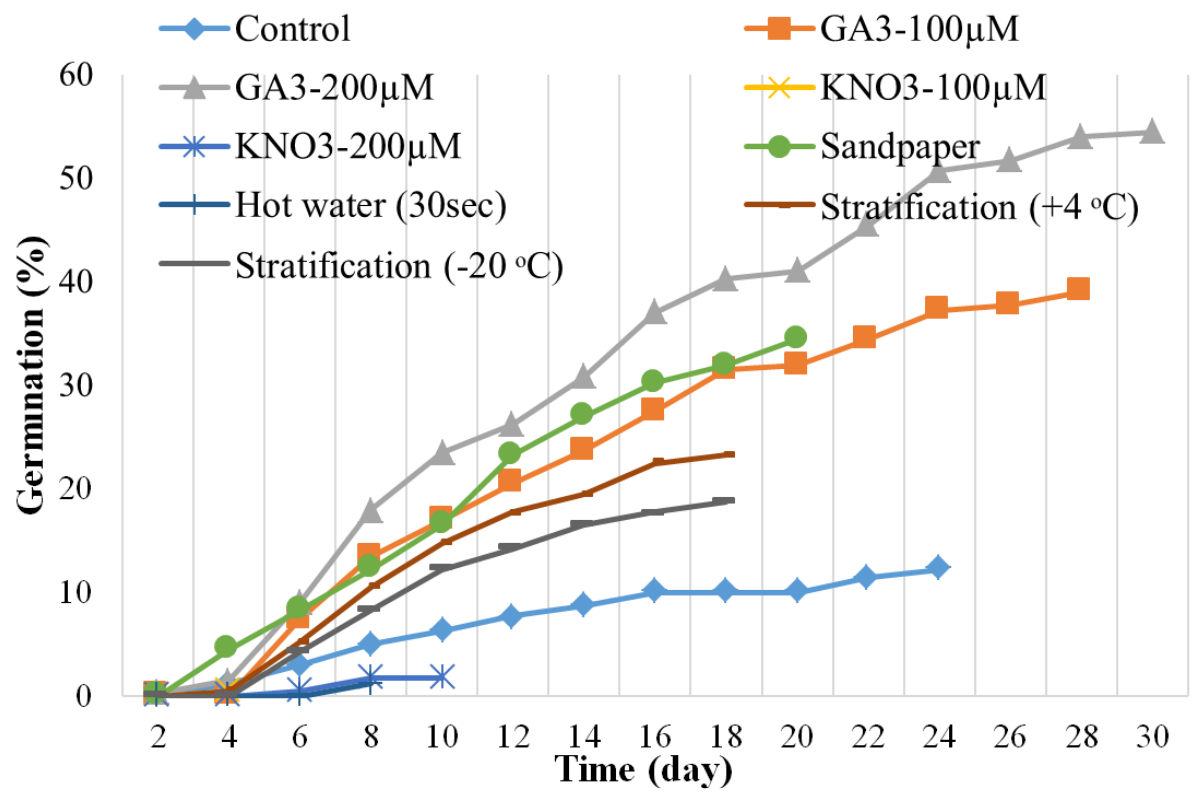

Fig. 3. Diagram of germination percentage and time for $V$. calycosum seeds under different treatments

\section{In vitro seed germination}

Different pre-treatments were used in vitro seed germination experiments. The effect of all pre-treatment of breaking dormancy was shown in Table 1.

Values of seed germination percentage speed of germination and time to $50 \%$ germination (T50) varied as $0-54.5 \%, 7.5-10.3$ and $8.5-13$, respectively. The influence of treatments on germination showed that $\mathrm{GA}_{3}$ (39 and $54.5 \%)$, mechanical scarification with sandpaper (34.5\%) and cold stratification $18.25 \%$ and $23.25 \%$ have increased germination percentage in $V$. calycosum seeds, while the $\mathrm{KNO}_{3}, \mathrm{NaCl}, \mathrm{HCl}$ and stratification with hot water treatments have significant decrease in germination percentage compared with control seeds (12.25\%) according to Duncan test $(\mathrm{P}<0.05)$. The speed of germination in the present study is low or insignificant in $\mathrm{GA}_{3}$ when compared the control $(\mathrm{P}<0.05)$. On the other hand, the SGs are higher than that of the control in scarification with sandpaper and cold stratification treatments $(\mathrm{P}<0.05)$. The time to $50 \%$ germination $(\mathrm{T} 50)$ increased ( $\mathrm{T} 50=11.5-13)$ in $\mathrm{GA}_{3}$ and sandpaper treatments whereas decreased in cold stratification treatments $($ T50 $=$ 8.5-8.7) when compared to control (Fig. 3).

\section{Discussion}

Seed dormancy is being incompletely understood, and therefore experimentation is important to choose treatments that improve germination (Zhou and Bao, 2010). Seed dormancy, dormancy breaking and germination responses in endemic species are generally unknown. This study describes the seed germination characteristics of endemic species $V$. calycosum. The highest germination percentages $(54.5 \%$ and $39 \%)$ were obtained with different concentrations of $\mathrm{GA}_{3}(100-200 \mu \mathrm{M})$, indicating that it was the most efficient treatment. Levels of 
endogenous plant growth regulators such as $\mathrm{GA}_{3}$ are believed to play a primary role in breaking dormancy (Zheng and Sun, 2009; Yücel and Yilmaz, 2009; Necajeva and Ievinsh, 2013) and endogenous $\mathrm{GA}_{3}$ deficiency can be recovered with exogenous $\mathrm{GA}_{3}$ application (Hilhorst and Karssen, 1992). In this study, exogenous application of gibberellic acid (GA3) at 100 and $200 \mu \mathrm{M}$ concentrations increased germination speed of $V$. calycosum seeds significantly $(\mathrm{P}<0.05)$. Dormancy break by $\mathrm{GA}_{3}$ is typical in seeds with non-deep and intermediate physiological dormancy (Schwienbacher $e t$ al., 2011). GA 3 supplementation appears to be the most successful treatment for stimulating germination in $V$. calycosum and this may be related to its non-deep or intermediate physiological dormancy characteristics.

The second highest germination percentage (34.5\%) was obtained with seeds mechanically scarified with sandpaper. Yildiztugay and Kucukoduk (2012) reported that scarification of lignified palisade cell layer of seeds with sandpapering triggers seed germination due to increase in water penetration.

Similarly, removing the cellular layer below the seed coat by mechanical scarification with sandpaper was reported to be the best method to overcome seed coat impermeability in many plant species (Sfairi et al., 2012; Asaadi et al., 2015). Therefore, our results indicated that seeds of $V$. calycosum possess physical dormancy due to the hard seed coat that can be broken down with mechanical scarification to get successful germination.

In our study, germination percentage was affected positively by cold stratifications (both in $+4{ }^{\circ} \mathrm{C}$ and $-20{ }^{\circ} \mathrm{C}$ for 7 days before starting the treatments), when compared with control groups. Also, highest speed of germination and shortened time for $50 \%$ germination $(P<0.05)$ were observed by cold stratifications $\left(+4{ }^{\circ} \mathrm{C}\right.$ and $\left.-20^{\circ} \mathrm{C}\right)$. Likewise, RBG Kew (2008) reported that high levels of seed germination after cold stratification at $2{ }^{\circ} \mathrm{C}$ were observed for Verbascum thapus L. and $V$. nigrum L. In our results, there were no significant differences between $4{ }^{\circ} \mathrm{C}$ and $-20^{\circ} \mathrm{C}$ in terms of GP, SG and T50 ( $\left.\mathrm{p}<0.05\right)$.

The germination percentages decreased to $2 \%, 1 \%$, and $0 \%$ after $\mathrm{KNO}_{3}, \mathrm{NaCl}, \mathrm{HCl}$ applications and hot stratification treatments, respectively. These results implied negative effect of salinity and acidity on seed germination in $V$. calycosum. It has been known that increased salinity levels affect water uptake by seed negatively, thereby inhibiting germination (Werner and Finkelstein, 1995). $\mathrm{NaCl}$ also was proposed as an inhibitory factor for the activities of some enzymes that may play crucial roles in seed germination (Katembe et al., 1998). On the other hand, different concentrations of $\mathrm{HCl}$ were applied to stimulate seed germination to soften thick seed coats directly or indirectly by stimulating fungi development on seed coats (Vleeshouwers et al., 1995).

However, in our study no germination with $\mathrm{HCl}$ applications was observed. These results may imply that this species is salt sensitive and cannot develop at lower $\mathrm{pH}$. Indeed, $V$. calycosum grows on saltless (EC: $0,251 \mathrm{mS} / \mathrm{cm}$ ) and slightly alkaline soil (Hilooğlu et al., 2016). A negative correlation between both salinity and acidity with germination was also reported in endemic Hymenocrater platystegius Recf.f (Teimouri and Mahallati, 2013). Hotwater treatment has been shown to increase germination by affecting factors such as seed coat permeability (Longer and Degago, 1996) and gaseous exchange (Corbineau et al., 1990). Furthermore, boiling seeds in water removes the cuticle and sometimes part of the pallisade layers of the seedcoat and can effectively break dormancy (FAO, 1983). It was also successfully used in seed germination of several endemic plant species (Luna et al., 2007; Choudhury et al., 2009). In our study, hot water treatment significantly decreased germination after $30 \mathrm{sec}$ incubation, and no germination observed after $1 \mathrm{~min}$ and $2 \mathrm{~min}$ incubation, possibly due to embryo damage. In addition, similar to our hot stratification results, Luna et al. (2007) reported no germination in Mediterranean endemic Verbascum rotundifolium Ten. seeds after heat-shock treatments at $80^{\circ} \mathrm{C}, 100^{\circ} \mathrm{C}$ and $120^{\circ} \mathrm{C}$.

\section{Conclusions}

In conclusion, the results of our experiments showed that giberellic acid, scarification with sandpaper and cold stratification pre-treatments increased germination rates in the rare endemic Verbascum calycosum. Breaking dormancy is known as a critical step to develop effective ex situ conservation strategies for rare and endemic plants. Therefore, the data obtained from this study will provide basic information to establish effective, low cost and quick ex situ conservation management for $V$. calycosum.

\section{Acknowledgements}

This work was supported by Scientific and Technological Research Council of Turkey-TUBITTAK (Project No 110T912).

\section{References}

Asaadi AM, Heshmati G, Dadkhah A (2015). Effects of Different Treatments to Stimulate Seed Germination of Salsola arbusculiformis Drob.Ecopersia3:1077-1088.

Asl MB, Sharivivash R, Rahbari A (2011). Effect of different treatments on seed germination of honey locust (Gleditschia triacanthos). Modern Applied Science 5:200-204.

Aytaç Z, Karavelioğulları FA, Ekici M (2005). Yok olan tür (EX) ve yetersiz veri (DD) basamağnda bulunan bazı taksonlar ile ilgili veriler [Data about some taxa of the missing species (EX) and inadequately framed (DD)]. Ot Sistematik Botanik Dergisi 12(1):9-20.

Bonner FT (1974). Seed testingin Seed of woody plants in the United States. Agriculture handbookNo.450 ServiceUSDA, Washington, USA.

$\mathrm{Bu} \mathrm{H}, \mathrm{Du} \mathrm{G}, \mathrm{Chen} \mathrm{X}, \mathrm{Xu}$ X, Liu K, Wen S (2008). Community wide germination strategies in an alpine meadow on the eastern QinghaiTibet plateau: phylogenetic and life-history correlates. Plant Ecology 195:87-98.

Choudhury BI, Khan ML, Das K (2009). Seed dormancy and germination in Gymnodladus assamicus: an endemic legume tree from Northeast India.Seed Science and Technology 37:582-588. 
380

Corbineau F, Bagniol S, CômeD (1990). Sunflower (Helianthus annuus L.) seed dormancy and its regulation by ethylene. Israel Journal of Botany 39:313-325.

Cousins SR, Witkowski ETF, Mycock DJ (2014). Seed storage and germination in Kumara plicatilis, a tree aloe endemic to Mountain Fynbos in the Boland, south-western Cape, South Africa. South African Journal of Botany 94:190-194.

Davis PH (1978). Flora of Turkey and the East Aegean Islands, Vol 6. Edinburg.

Ekim T, Koyuncu M, Vural M, Duman H, Aytaç Z, Adıgüzel N (2000). Red data book of Turkish plants (ferns and seed plants). Publications of Association of Turkey's Nature Conservation, Ankara.

ErikS, Tarikahya B (2004). Türkiye florası üzerine [Flora of Turkey].Journal of Kebikeç 17(1):139-163.

FAO (1983). Handbook on seeds of dryzone acacias (based on the work of Doran JC et al.). Rome.

Farooq M, Basra SMA, Hafeez K, Ahmad N (2005). Thermal hardening: a new seed vigor enhancement tool in rice. Journal of Integrative Plant Biology 47:187-193.

Hilhorst HWM, Karssen CM (1992). Seed dormancy and germination: the role of abscisic acid and gibberellins and the importance of hormone mutants. Plant Growth Regulation 11:225-238.

Hilooğlu M (2016). Determination of threatening ecological and genetic factors for some endemic plant species distributed in Erzincan. $\mathrm{PhD}$ Thesis, Anadolu Univ, Turkey.

ISTA (International Seed Test Association) (1985). The germination test. Seed Science and Technology 13:307-463.

Jones CD, Stevens MR, Jolley VD, Hopkins BG, Jensen SL, Turner D, Stettler JM (2016). Evaluation of thermal, chemical, and mechanical seed scarification methods for $4 \mathrm{Great}$ Basin lupine species. Native Plants Journal 17:5-17.

Kandemir A, Makbul S (2004). Erzincan yöresinde yayllş gösteren bazı nadir bitki türleri üzerine gözlemler [The observations on some rare plant species grown up in Erzincan]. Erzincan Eğitim Fakültesi Dergisi 6:37-49.

Kandemir A, Sevindi C, Korkmaz M, Çelikoğlu Ş (2015). IUCN threatened categories on endemic taxa which is specific to Erzincan (Turkey). Bağbahçe Bilim Dergisi 2:43-65.

Katembe WJ, Ungar IA, Mitchell JP (1998). Effect of salinity on germination and seedling growth of two Atriplex species (Chenopodiaceae). Annals of Botany 82:167-175.

Longer DE, Degago Y (1996). Field weathering potential of normal and hardseeded soybean genotypes. Seed Science and Technology 24:273280.

Luna B, Moreno JM, Cruz A, Fernandez-Gonzalez F (2007). Heat-Shock and seed germination of a group of Mediterranean plant species growing in a burned area: an approach based on plant functional types. Environmental and Experimental Botany 60:324333.
Menges ES (1986). Predicting the future of rare plant populations: demographic monitoring and modelling. Natural Areas Journal 6:1325.

Necajeva, J, Ievinsh G (2013). Seed dormancy and germination of an endangered coastal plant Eryngium maritimum (Apiaceae). Estonian Journal of Ecology 62:150-161.

Nydegger-Hügi M (2002). Dreizehnte und letste Erganzungen zu P.H. Davis [Flora of Turkey and the East Aegean Islands]. Bahunia 16:33-35.

Peng DL, Hu XJ, YangJ, Sun H (2017). Seed dormancy, germination and soil seed bank of Lamiophlomis rotata and Marmoritis complanatum (Labiatae), two endemic species from Himalaya-Hengduan Mountains. Plant Biosystems. doi: 10.1080/11263504.2017.1311959.

RBG Kew (2008). Royal Botanic Gardens Kew, Seed Information Database (SID) Ver.7.1. Retrieved 2017 January from 5 http://datakew.org/sid.

Schemske DW, Husband BC, Ruckelshaus CG, Goodwillie C, Parker IM, BishopJG (1994). Evaluating approaches to the conservation of rare and endangered plants. Ecology 75:584-606.

SchwienbacherE, Navarro-CanoJA, Neuner G,Erschbamer B (2011).Seed dormancy in alpine species. Flora 206:845-856.

Sfairi Y, Lahcen O, Feddy MNA, Abbad A (2012). Dormancy-breaking and salinity/water stress effects on seed germination of atlas cypress, an endemic and threatened coniferous species in Morocco. African Journal of Biotechnology 11:4385-4390.

Teimouri MS, Mahallati MN (2013). Seed germination and breaking of seed dormancy techniques for endemic Hymenocrater platystegius. International Journal of Agriculture and Crop Sciences 6:885-889.

Vleeshouwers LM, Bowmeester HJ, Karssen CM (1995). Redefining seed dormancy: an attempt to integrate physiology and ecology. Journal of Ecology 83:1031-1037.

Werner JE, Finkelstein RR (1995). Arabidopsis mutants with reduced response to $\mathrm{NaCl}$ an osmotic stress. Physiologia Plantarum 93:659-666.

Yildiztugay E, Kucukoduk M (2012). Dormancy breaking and germination requirements for seeds of Sphaerophysa kotschyana Boiss. Journal of Global Biosciences 1:20-27.

Yücel E (2000). Effects of different salt $(\mathrm{NaCl})$, nitrate $\left(\mathrm{KNO}_{3}\right)$ and acid $\left(\mathrm{H}_{2} \mathrm{SO}_{4}\right)$ concentrations on the germination of some Salvia species seeds. Seed Science and Technology 28:853-860.

Yücel E, Yllmaz G (2009). Effects of different alkaline metal salts $(\mathrm{NaCl}$, $\left.\mathrm{KNO}_{3}\right)$, acid concentrations $\left(\mathrm{H}_{2} \mathrm{SO}_{4}\right)$ and growth regulator $\left(\mathrm{GA}_{3}\right)$ on the germination of Salvia cyanescens Boiss. \& Bal. seeds. Gazi University Journal of Science 22:123-127.

Zheng Y, Sun W (2009). Seed germination of Huagaimu, a critically endangered plant endemic to southeastern Yunnan, China. HortTechnology 1:427-431.

Zhou Z, Bao W (2011). Levels of physiological dormancy and methods for improving seed germination of four rose species. Scientia Horticulturae 129(4):818-824. 